\section{Mudbanks and fisheries along the Kerala coast - myth and reality}

\author{
S. Prasanna Kumar ${ }^{1, *}$, P. K. Dinesh Kumar ${ }^{2}$, \\ K. R. Muraleedharan ${ }^{2}$, Grinson George ${ }^{3}$, \\ Dayana Mathew ${ }^{2}$, V. Kripa ${ }^{3}$, R. Jeyabaskaran ${ }^{3}$, \\ N. Ramaiah ${ }^{1}$, A. Gopalakrishnan ${ }^{3}$ and \\ S. W. A. Naqvi ${ }^{1}$ \\ ${ }^{1}$ CSIR-National Institute of Oceanography, Dona Paula, \\ Goa 403 004, India \\ ${ }^{2}$ CSIR-National Institute of Oceanography Regional Centre, \\ Dr Salim Ali Road, Kochi 682 018, India \\ ${ }^{3}$ Central Marine Fisheries Research Institute, \\ Ernakulam North PO, Kochi 682 018, India
}

\begin{abstract}
Mudbanks, a unique coastal oceanographic phenomenon occurring along the southwest (SW) coast of India during the $\mathrm{SW}$ monsoon season, are synonymous with the fishery of this region. Here we examine the validity of the popular notion that mudbanks directly support rich fisheries, using a high temporal resolution water column data collected from the Alappuzha mudbank region in Kerala during April to September 2014, in conjunction with fisheries data. Our study reveals that the upwelling which occurs during the SW monsoon season along this coast brings oxygendeficient subsurface water to the upper water column. Escaping the oxygen-depleted waters, the fish aggregate within a thin upper layer allowing easy visual identification and capture of fish shoals. This process occurs throughout the coast and is not confined just to the mudbanks. Mudbank being a calm region, traditional fishermen using non-motorized country craft were able to carry out fishing within this region only during the SW monsoon. With the induction of motorized and mechanized fishing, the link between mudbanks and fisheries is becoming less prominent, although the former still continue to be important fish landing centres.
\end{abstract}

Keywords: Mudbank, monsoon, suspended sediments, pelagic and demersal fishery, upwelling.

MUDBANKS are unique coastal oceanographic features that occur seasonally during the southwest (SW) monsoon (June-September) at certain locations along the Kerala coast. They are characterized by a high load of suspended sediments, often exceeding $1000 \mathrm{mg} / \mathrm{l}$ (ref. 1) and largely consisting of clay-sized particles which are $<1 \mu \mathrm{m}$ in $\operatorname{size}^{2,3}$. Mudbanks are distinguished by very low wave activity (height $<0.5 \mathrm{~m}$ ) in the midst of turbulent monsoonal waves, usually $2-5 \mathrm{~m}$ in height. Mudbanks occur close to the coast, at water depth ranging from 7 to $15 \mathrm{~m}$, in a semi-circular shape with a typical alongshore length of $4 \mathrm{~km}$ and offshore distance up to $8 \mathrm{~km}$ (refs 4 ,

\footnotetext{
*For correspondence. (e-mail: prasanna.ocean@gmail.com)
}

5). Although there are about 20 locations where the occurrence of mudbanks has been reported in the past (Figure 1, top right panel), the phenomenon does not occur at all locations every year. However, at some of these sites, especially off Alappuzha (Figure 1), the occurrence is more frequent, almost every year. The mudbanks are mostly located in the vicinity of river mouths or lagoons, with the exception of the most prominent system off Alappuzha, which is located well away from the outlet of any river or lagoon. There is a growing perception that the occurrence of mudbanks along the Kerala coast used to be more frequent in the past, but of late there has been a declining trend in their numbers as well as duration and intensity of their formation, for reasons that are not known. However, there are no robust time-series data to corroborate the same.

Mudbanks of Kerala are synonymous with rich fisheries. Huge quantities of pelagic as well as demersal fish are harvested from the mudbank regions every year by fishermen using country crafts. The unusually high concentration of suspended mud/sediment leads to the damping of incoming high monsoon waves ${ }^{6,7}$. This protects the adjoining beaches from erosion, which commonly occurs along the Kerala coast during SW monsoon season ${ }^{8,9}$. Mudbanks of Kerala have great socio-economic relevance as they support livelihoods of fishermen and protect beaches from erosion during the hostile weather conditions.

In spite of the excellent records of mudbanks of Kerala, dating as far back as 1678 (ref. 10), and large body of research resulting in over 100 research papers and over a dozen $\mathrm{PhD}$ theses ${ }^{11}$, the phenomenon of mudbanks and their link with fisheries remains an enigma ${ }^{12}$. The most important questions that still elude us are: (1) what triggers the fluid mud formation at select welldefined locations along the Kerala coast during SW monsoon leading to the formation of mudbanks and (2) why fishes, both pelagic as well as demersal, aggregate within the mudbank region. This motivated us to undertake an observational programme in 2014 at Alappuzha, the site with most frequent occurrence of mudbanks ${ }^{5}$. While the first question is a subject matter of another publication, here we address the second question.

A multi-institutional observational programme was jointly initiated by the CSIR-National Institute of Oceanography (CSIR-NIO), Goa and Kochi, and Central Marine Fisheries Research Institute (CMFRI), Kochi to collect multidisciplinary time-series data from Alappuzha mudbank region during April to September 2014. An observational station was selected at Punnapra $\left(76^{\circ} 22^{\prime} 16.8^{\prime \prime} \mathrm{E}\right.$ and $\left.9^{\circ} 25^{\prime \prime} 1.4^{\prime \prime} \mathrm{N}\right)$ in Alappuzha district at a nominal water depth of $6 \mathrm{~m}$ (Figure 1, bottom panel) from where high-resolution in situ data were collected. The weekly time-series data collection was initiated on 22 April on-board CMFRI's FV Silver Pompano, well ahead of the onset of SW monsoon and continued up to 


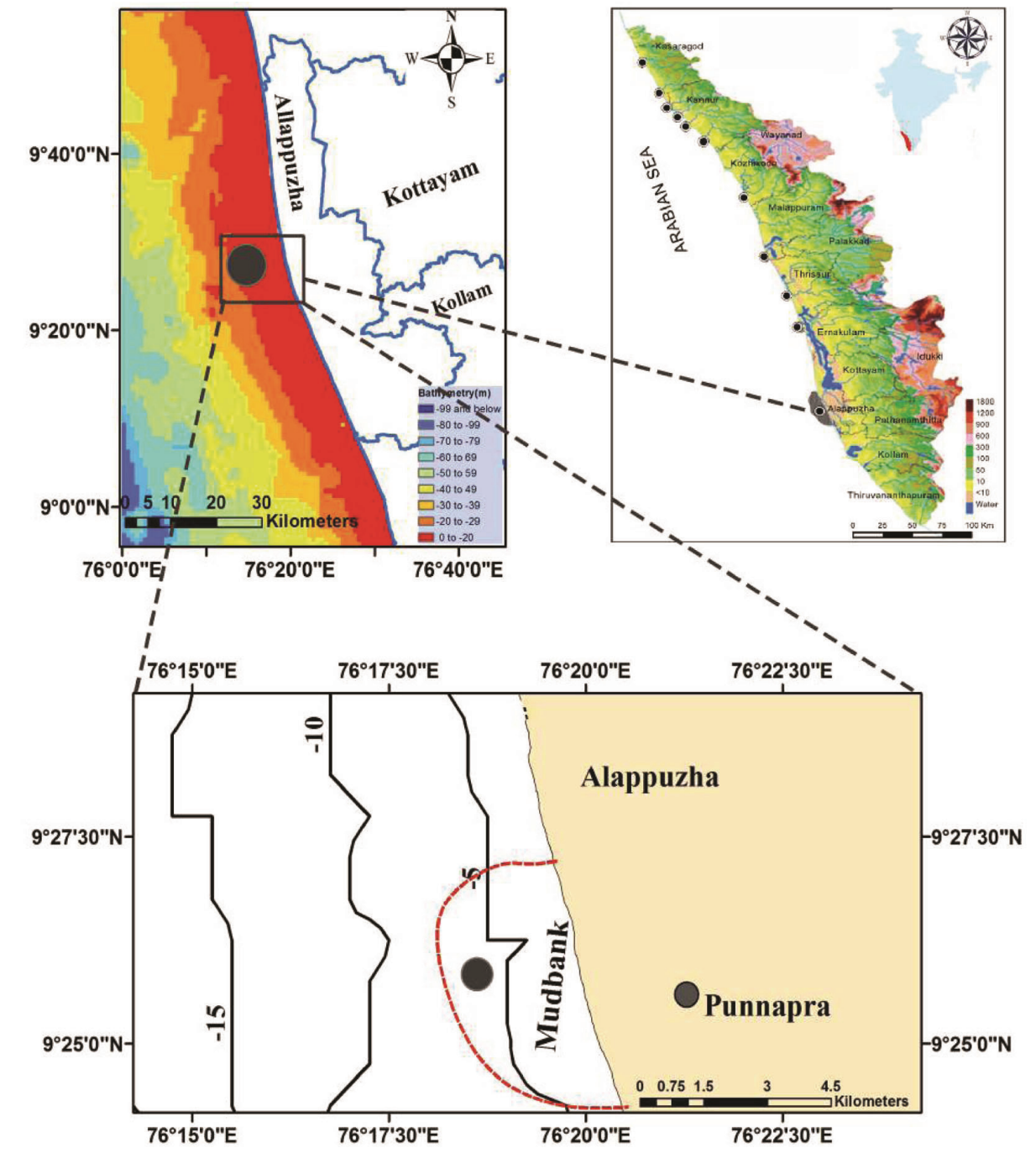

Figure 1. (Top panel, right) Map showing the locations of mudbanks along the Kerala coast (filled dark circles). (Top panel, left) The region of mudbank in Alappuzha district of Kerala denoted by a dark rectangular box enclosing a dark filled circle (the colour shading in the map is for depth (m). (Bottom panel) The outer periphery of the Alappuzha mudbank (red broken line), the depth contours (solid black lines) and the location of the sampling station (dark circles). See text for details.

20 September 2014 well after the withdrawal of SW monsoon. In addition to the CMFRI vessel, which was used mainly for fishing operations and fisheries data collection, a fishing boat was used for collection of oceanographic data and water samples.

Vertical profiles of temperature and salinity were obtained using a sea bird electronics (SBE) 19 plus conductivity-temperature-depth (CTD) probe attached with a turbidity sensor. A $5 \mathrm{~L}$ Niskin bottle was used for collecting water samples from near surface, 2, 4 and $6 \mathrm{~m}$ depths. The data on temperature, salinity, turbidity and dissolved oxygen were collected at weekly intervals. An automated weather station (AWS) developed at CSIRNIO, Goa, was mounted at $10 \mathrm{~m}$ height on a building located close to the station (Punnapra) for obtaining the time-series data on wind speed, direction, pressure and relative humidity from 1 May to 30 September 2014. These data were collected at 10 min interval with a sampling frequency of $1 \mathrm{~s}$. Daily mean values and standard deviations were calculated for preparing the plots. All the sensors were calibrated before the observations were initiated. Table 1 provides the measurement ranges and accuracies of the sensors used for data collection. The data on average daily rainfall were obtained from tropical rainfall measuring mission (TRMM) having a grid resolution of $0.25^{\circ}$ (http://trmm.gsfc.nasa.gov) from a location close to the sampling station. The dissolved oxygen in sea water was measured following the Winkler method ${ }^{13}$. The fishery data used in the present study consisted of fish catch generated from the landing centres within and outside the mudbank region in Alappuzha. From the above data, catch per unit effort (CPUE) has been calculated. 
Time evolution of surface meteorological data showed the occurrence of five distinct atmospheric events during the study period (Table 2), each marked by a sudden drop in atmospheric pressure followed by an increase in wind speed, relative humidity and rainfall (Figure 2, shaded region). The first event occurred from 4 to 10 May 2014

Table 1. Range and accuracy instrumental of oceanographic and atmospheric data collected using CTD and CSIR-NIO AWS respectively (see text for details)

\begin{tabular}{lll}
\hline Parameter & Range & \multicolumn{1}{c}{ Accuracy } \\
\hline Temperature $\left({ }^{\circ} \mathrm{C}\right)$ & $-5-35$ & \pm 0.005 \\
Conductivity $(\mathrm{S} / \mathrm{m})$ & $0-9$ & \pm 0.0005 \\
Turbidity (NTU) & $0-25$ & \pm 0.01 \\
Pressure (m) & $0-100$ & \pm 0.1 \\
& & of full scale $(\sim 0.1 \mathrm{~m})$ \\
Wind speed (m/s) & $0-60$ & \pm 0.2 \\
Wind direction $\left({ }^{\circ}\right)$ & $0-360$ & \pm 3 \\
Pressure (mbar) & $800-1060$ & \pm 0.4 \\
Relative humidity $(\%)$ & $0-100$ & \pm 3 \\
\hline
\end{tabular}
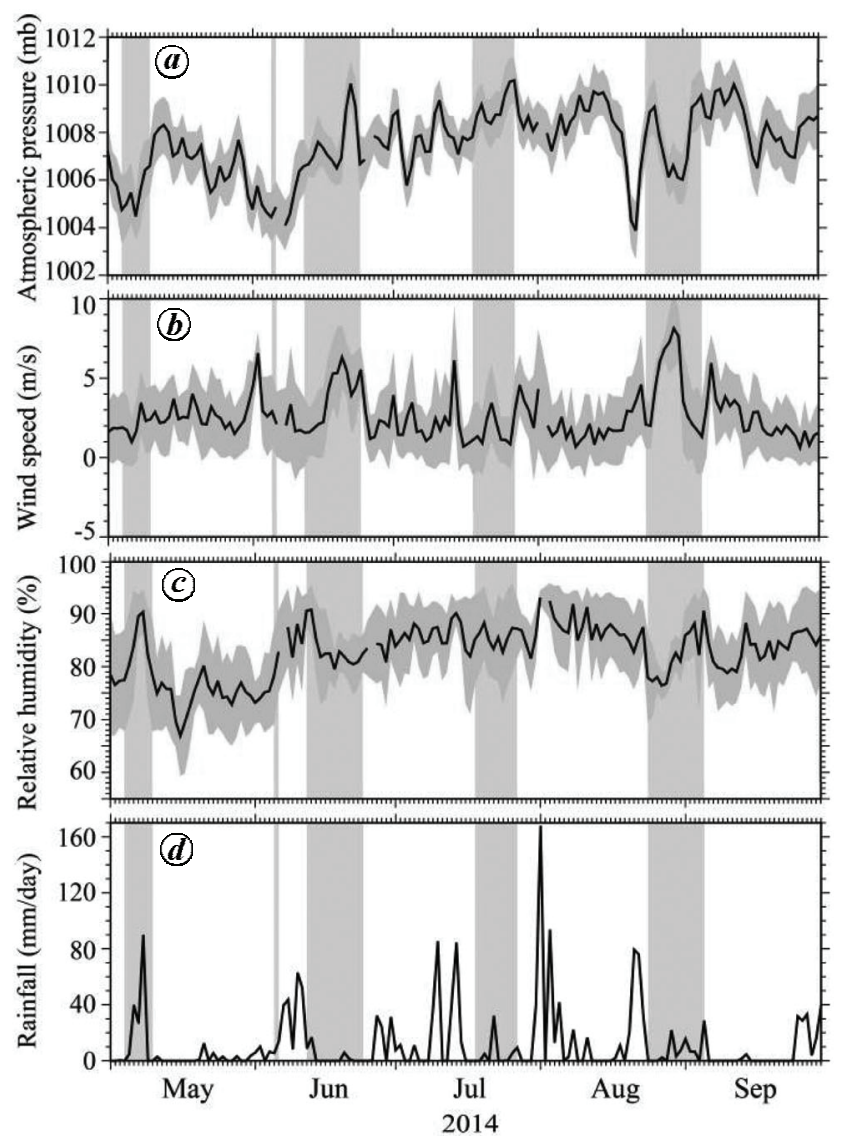

Figure 2. Time series of daily averaged data on (a) atmospheric pressure $(\mathrm{mb}),(\boldsymbol{b})$ wind speed $(\mathrm{m} / \mathrm{s}),(\boldsymbol{c})$ relative humidity $(\%)$ and $(\boldsymbol{d})$ rainfall (mm/day) during the period 1 May to 30 September 2014. The daily averages in panels $(\boldsymbol{a})-(\boldsymbol{c})$ have been generated by averaging data acquired at $10 \mathrm{~min}$ interval and the horizontal shadings are the associated standard deviation. The vertical shadings are the five meteorological events (see Table 2 for details) that occurred during the study period. when the atmospheric pressure dropped by $4 \mathrm{mb}$, followed by a strong westerly wind $(5 \mathrm{~m} / \mathrm{s}$ during in situ observations) and high precipitation (mean value of $27 \mathrm{~mm} /$ day). The second event was the onset of SW monsoon on 6 June 2014, when the atmospheric pressure dropped by $6 \mathrm{mb}$, the wind gust speed exceeded $10 \mathrm{~m} / \mathrm{s}$ (Table 2) and average rainfall was $25.7 \mathrm{~mm} /$ day. Subsequently, three more episodic atmospheric events were noticed during 12 June to 24 June, 18 to 27 July and 24 August to 5 September 2014 (Table 2). These three events were associated with marked decrease in atmospheric pressure, increased wind speeds and humidity accompanied by intense rainfall over the study region (Figure 2 and Table 2).

The above atmospheric events are expected to impact the underlying water column. The high winds and waves associated with these episodic events could potentially transfer large amounts of energy through the water column to the bottom boundary layer through frictional coupling and momentum transfer. The onshore upwelling current will also aid the movement of bottom sediments. In order to study this, we examined the time evolution of water column turbidity measured by the CTD probe. Consistent with the atmospheric episodes, a corresponding increase in the water column turbidity was observed associated with all five episodic events (Figure 3, top panel). For example, during the first event, turbidity of the water column showed an increase from $5 \mathrm{NTU}$ in the upper $5 \mathrm{~m}$ depth to $>20 \mathrm{NTU}$ towards the bottom. Note that the grey shaded portion in Figure 3 indicates the depths where turbidity was in excess of 25 NTU, which is beyond the measurement limit of the CTD turbidity sensor. This implies that the water column close to the bottom had very high suspended sediment load forming the fluid mud layer. From these measurements, the inferred thickness of this layer was found to vary from $0.5 \mathrm{~m}$ to $2 \mathrm{~m}$. Thus, it appears that the high input of energy to the bottom boundary layer by sporadic high winds triggered by the atmospheric events along with the prevailing high waves associated with the SW monsoon was able to resuspend the bottom sediments, thereby increasing the turbidity of the water column.

An examination of the time-evolution of the water column temperature showed the appearance of cold subsurface water with time, a signature of upwelling (Figure 3 , middle panel). Associated with the onset of SW monsoon, the prevailing northwesterly winds along the coast of Kerala (figure not shown), including Alappuzha, kickstarted the upwelling process, which is a wind-driven Ekman response of the water column. A sharp decline of $3^{\circ} \mathrm{C}$ in subsurface water temperature occurred during the initial phase of upwelling, which further intensified with the progress of SW monsoon. Though the process of upwelling was sustained throughout the SW monsoon period of 2014 (June to September), the occurrence of cold waters originating from the bottom was sporadic and 
Table 2. Changes in surface meteorological parameters associated with the five episodic atmospheric events that occurred in the Arabian Sea which impacted the study region during 1 May to 30 September 2014

\begin{tabular}{|c|c|c|c|c|}
\hline $\begin{array}{l}\text { Atmospheric events } \\
\text { and their duration }\end{array}$ & $\begin{array}{l}\text { Pressure drop } \\
\qquad(\mathrm{mb})\end{array}$ & $\begin{array}{l}\text { Wind gust } \\
(\mathrm{m} / \mathrm{s})\end{array}$ & $\begin{array}{l}\text { Relative humidity } \\
\qquad(\%)\end{array}$ & $\begin{array}{c}\text { Rainfall } \\
(\mathrm{mm} / \text { day })\end{array}$ \\
\hline \multicolumn{5}{|l|}{ Episode 1} \\
\hline $\begin{array}{l}\text { Low pressure (mean, SD) } \\
\text { 4-10 May } 2014\end{array}$ & $\begin{array}{l}1002.2-1006.4 \\
(1005.4 \pm 1.5)\end{array}$ & $\begin{array}{l}0-10.40 \\
(2.06 \pm 2.26)\end{array}$ & $\begin{array}{l}57.6-94.9 \\
(83.2 \pm 10.7)\end{array}$ & 27.1 \\
\hline \multicolumn{5}{|l|}{ Episode 2} \\
\hline $\begin{array}{l}\text { Onset of monsoon (mean, SD) } \\
6 \text { June } 2014\end{array}$ & $\begin{array}{l}1003.1-1005.6 \\
(1003.8 \pm 1.1)\end{array}$ & $\begin{array}{l}13.51-16.40 \\
(15.30 \pm 2.04)\end{array}$ & $\begin{array}{l}88.4-98.5 \\
(90.1 \pm 7.8)\end{array}$ & 25.7 \\
\hline $\begin{array}{l}\text { Episode } 3 \\
\quad \text { Cyclone (mean, SD) } \\
\text { 12-24 June } 2014\end{array}$ & $\begin{array}{l}1004.4-1009.3 \\
(1007.6 \pm 1.2)\end{array}$ & $\begin{array}{l}0-16.70 \\
(3.83 \pm 2.91)\end{array}$ & $\begin{array}{l}66.3-92.7 \\
(83.2 \pm 8.9)\end{array}$ & 15.2 \\
\hline $\begin{array}{l}\text { Episode } 4 \\
\text { Depression (mean, SD) } \\
18 \text { to } 27 \text { July } 2014\end{array}$ & $\begin{array}{l}1006.1-1009.4 \\
(1008.8 \pm 1.12)\end{array}$ & $\begin{array}{l}0-13.70 \\
(1.74 \pm 2.40)\end{array}$ & $\begin{array}{l}64-95.2 \\
(85.6 \pm 9.6)\end{array}$ & 37.0 \\
\hline $\begin{array}{l}\text { Episode } 5 \\
\text { Depression (mean, SD) } \\
24 \text { August-5 September } 2014\end{array}$ & $\begin{array}{l}1001.9-1008.4 \\
(1007.6 \pm 1.21)\end{array}$ & $\begin{array}{l}0-15.7 \\
(4.27 \pm 3.20)\end{array}$ & $\begin{array}{l}68-95.7 \\
(81.9 \pm 10.2)\end{array}$ & 45.2 \\
\hline
\end{tabular}

All parameters, except rainfall, are expressed as range and (mean \pm standard deviation). Rainfall is expressed as mean.

in tandem with wind events. This clearly indicated that upwelling intensity was controlled by the strong winds initiated by the atmospheric episodic events. The timeevolution of dissolved oxygen within the water column showed a progressive decline in concentration (Figure 3, bottom panel), especially in the subsurface layers, in tandem with the upward propagation of colder waters. The concentration fell lower than $50 \mu \mathrm{M}$ below a thin, well-oxygenated surface layer after the onset of SW monsoon, progressively expanding upward along with colder waters. Thus, upwelling brings low temperature $\left(<26^{\circ} \mathrm{C}\right)$, high salinity ( $>35.5$ psu, not shown) and oxygen-depleted $(<75 \mu \mathrm{M})$ water that is overlain by a thin, warm, fresher and oxygenated lens within the mudbank. This lens persists because of heavy rainfall during the SW monsoon period, resulting in strong stratification in the upper layer which prevents/curtails vertical mixing. The twolayered structure is maintained at such a shallow depth despite strong winds. The resultant hypoxic conditions in the lower layer within the mudbank have implications to fishery, as discussed below.

To examine the link between mudbank formation and fisheries, we analysed the fishery potential of mudbank and non-mudbank regions with the help of CPUE data within Alappuzha district for the 2013, 2014 and 2015. In this district, a unique one-man-operated expanded polystyrene thermocol craft with gill net was used for fishing along with several other motorized and non-motorized boats. The CPUE data from 2013 to 2015 showed only minor difference between the mudbank and non-mudbank regions (Figure 4). Based on the positive and negative year-to-year difference in CPUE, we infer that there is no preferential fish aggregation in the mudbank region.
Further, examination of different fish species within the mudbanks reveals high abundance of a benthic fish Trypauchen vagina (not a commercial fishery), considered to be an indicator of mudbank formation. In addition, there was a progressive succession of other benthic crustaceans such as Metapenaeus dobsoni of higher size (popularly known as 'Poovalan Chemmeen') and Fenneropenaeus indicus, Indian white shrimp that occurs in both mudbank and non-mudbank regions. The apparent cause for the upward movement of this benthic fish and benthic crustaceans is the presence of hypoxic waters associated with upwelling ${ }^{14}$. Apart from the benthic species, notable landings of small pelagic fish such as Indian oil sardines, mackerel and anchovies are the major contributors to fishery in this region, encompassing both mudbank and non-mudbank regions. Note that the small pelagic fishery is closely linked to the occurrence of high phytoplankton (chlorophyll) that is driven by coastal upwelling. Thus, we infer that the rich fisheries during the upwelling season are not only limited to the mudbank region but all along the coast that comes under upwelling regime. The hypoxic waters brought up by upwelling drive the upward migration of both benthic and pelagic fish to the thin oxygenated layer close to the surface. This makes it easy for fishermen to identify the shoals visually and catch them with ease. Before the advent of motorized boats and mechanized fishing, the artisanal fishermen with their country craft could operate only within the tranquil of the mudbank for fishing. This is perhaps the reason why mudbanks are synonymous with fisheries. Even today, with the induction of motorized boats and mechanized fishing along the Kerala coast, traditional fishermen still use non-motorized and non-mechanized boats within the 


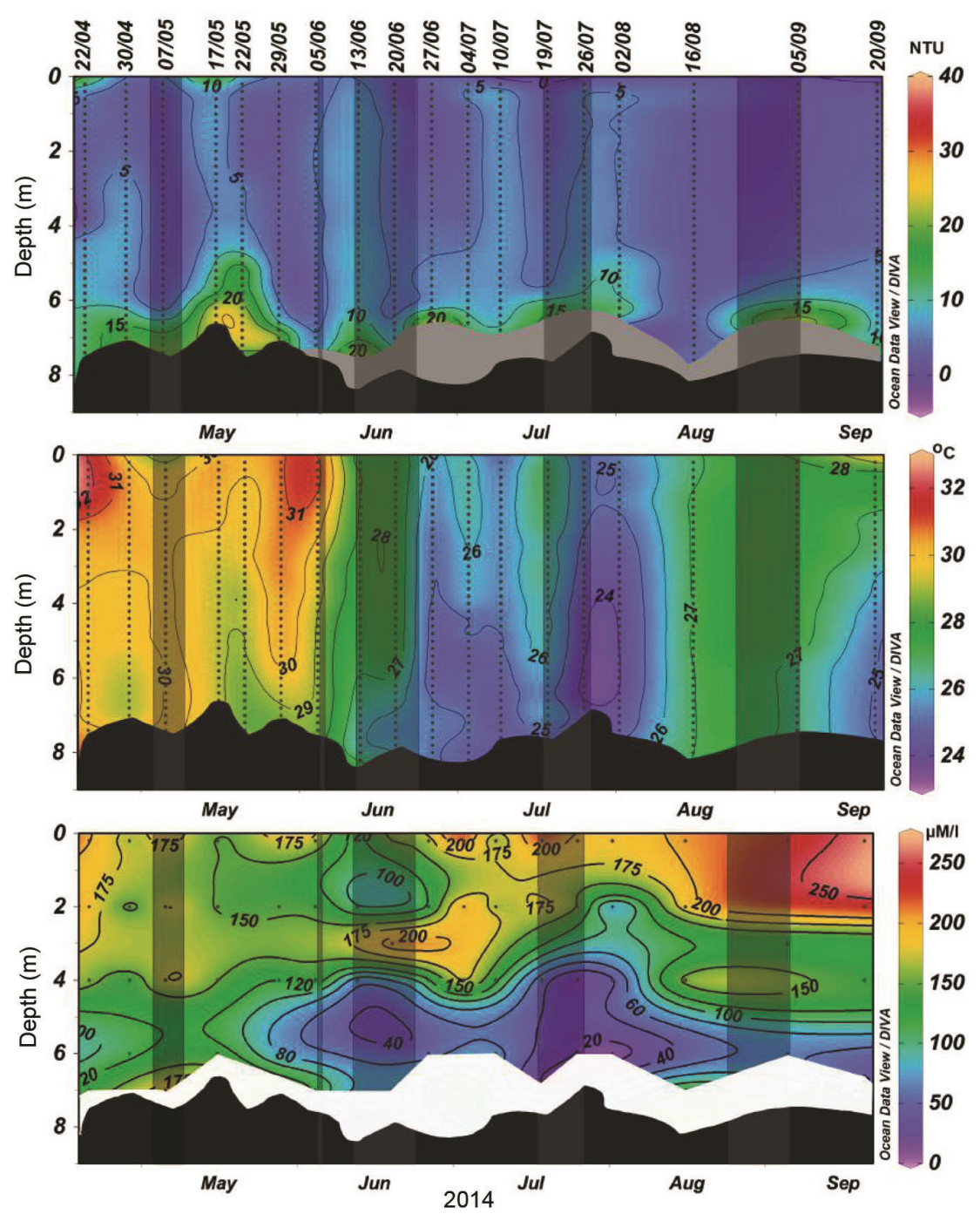

Figure 3. Time-series data on (top panel) water column turbidity (NTU), (middle panel) temperature $\left({ }^{\circ} \mathrm{C}\right)$ and (bottom panel) dissolved oxygen $(\mu \mathrm{M} / 1)$ during the period 22 April to 30 September 2014 . The black shading at the bottom of each panel shows the bottom depth. (Top panel) $X$-axis labels denote the date on which water column sampling was carried out; the grey shading near the bottom marks the region where turbidity is beyond the upper measuring limit of the turbidity sensor, implying prevalence of fluid mud. (Bottom panel) The white shading indicates missing data.

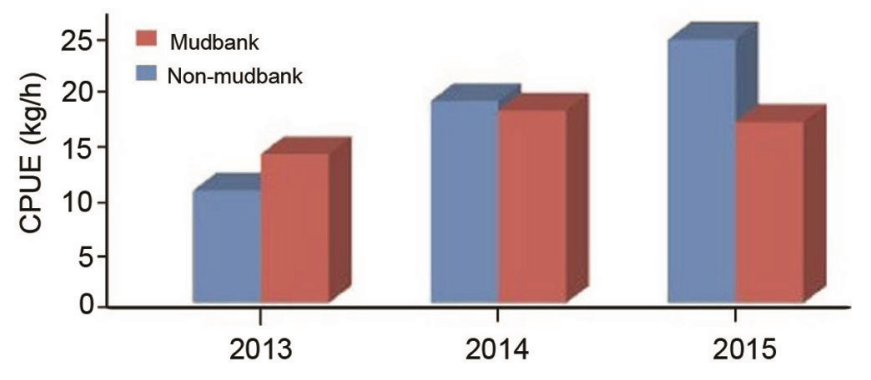

Figure 4. Fish catch per unit effort (CPUE; $\mathrm{kg} / \mathrm{h}$ ) of non-motorized boats in the mudbank and non-mudbank regions of Alappuzha district.

mudbank to get good fish catch. However, the comparable fish catch data from both within and outside the mud- bank region underscore the fact that the mudbanks per se do not support higher fish production; rather they provide a calm condition suitable for fishing and landing the catch during the otherwise rough SW monsoon season. In fact, the coastal upwelling process that occurs during SW monsoon brings hypoxic waters to the upper water column, thereby progressively moving both benthic and small pelagic fishes towards the surface waters all along the coast.

In summary, the present study reveals the reason for the aggregation of pelagic and demersal fishes in the thin, oxygenated upper layers along the coastal regions of Kerala, irrespective of the occurrence of mudbanks. The coastal upwelling-driven phytoplankton blooms sustain the small pelagic fishery typical of an eastern boundary 


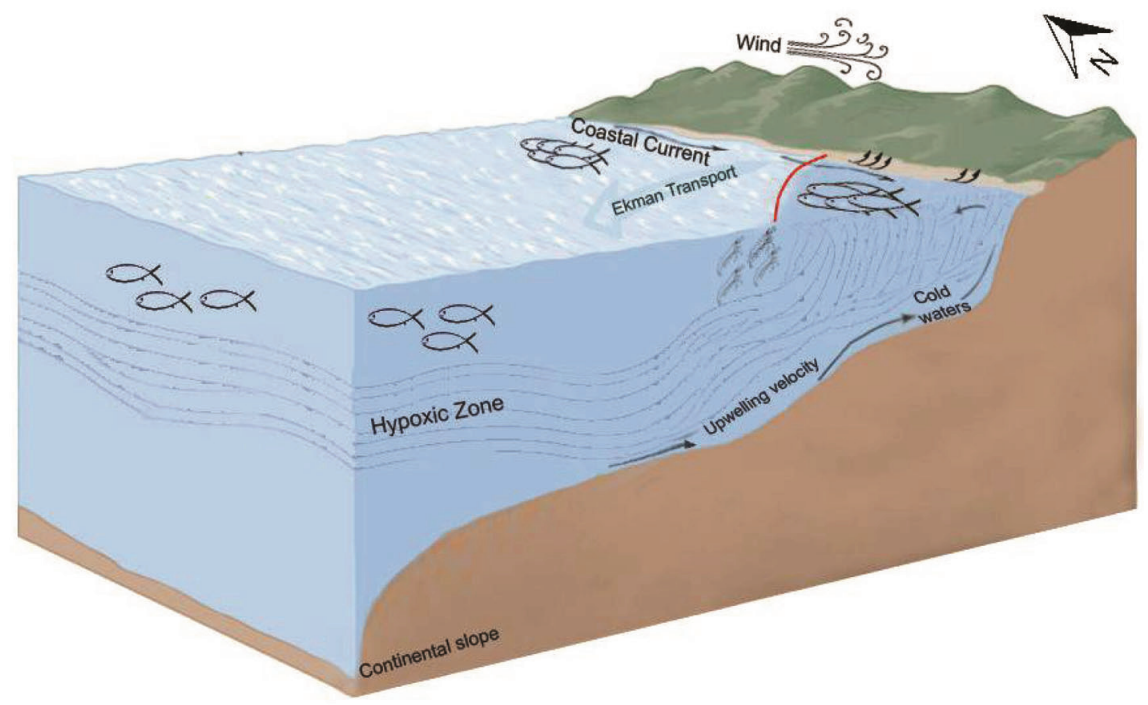

Figure 5. Schematic representation of the coastal upwelling process (bunch of thin lines moving vertically upwards along the coastal region) that co-exists with the mudbank. The semi-circular solid red line indicates the region of mudbank along the coast of Alappuza. Upwelling brings cold and nutrient-rich water with very low dissolved oxygen from the subsurface to the surface along the coast, making the waters hypoxic. The upwelling-driven phytoplankton bloom sustains the small pelagic fish such as mackerels and sardines during this period. For feeding, these pelagic fish swim against the coastal current which is southerly along the coast, indicated by the solid black arrows close to the coast.

ecosystem during SW monsoon, while the hypoxic subsurface waters located just beneath the thin, warm, lower salinity lens force aggregation of both demersal and pelagic fishes in the upper few metres. Although the coastal current moves southward along the coast of Kerala during SW monsoon season, upwelling progressively moves from south to north with time ${ }^{15}$, and the pelagic fishes may also migrate northward for feeding. Figure 5 is a schematic representation of this process. We conclude that the mudbank regions do not provide any special environment for enhanced fish production; rather they only help the artisanal fishermen to fish in the calm regions when the other near-shore regions are turbulent with high waves making the operation of non-motorized country boats difficult, if not impossible.

1. Kurup, P. G., Studies on the physical aspects of the mudbanks along the Kerala coast with reference to the Purakkad mudbank. Bull. Dept. Mar. Sci., 1977, 8, 1-72.

2. Dora, Y. L., Damodaran, R., Jose and Anto, V., Texture of Narakkal mudbank sediments. Bull. Dept. Mar. Biol. Oceanogr., 1968, $4,1-10$.

3. Venkatachala, B. S., Kar, R. R., Suchindan, G. K., Ramachandran, K. K. and Kumar, M., Study on the sedimentary facies, sporepollen and palynodebris of mudbank and Vembanad Lake, Kerala. Geophytology, 1992, 22, 245-254.

4. Gopinathan, C. K. and Qasim, S. Z., Mudbanks of Kerala their formation and characteristics. Indian J. Mar. Sci., 1974, 3, 105-114.

5. Silas, E. G., Mudbanks of Kerala-Karnataka: need for an integrated study. Bull. Cent. Mar. Fish. Res. Inst., 1984, 31, $2-7$.

6. Macpherson, H. and Kurup, P. G., Wave dampening at Kerala mudbank. Indian J. Mar. Sci., 1981, 10, 154-160.

7. Mathew, J., Baba, M. and Kurian, N. P., Mudbanks of the south west coast of India I: wave characteristics. J. Coast. Res., 1995, 11, 168-178.

8. Erattupuzha, J. J. and Raman, H., Shore erosion and shore protection in Kerala. In Proceedings of the Symposium Coastal Erosion and Protection in Kerala, Kerala Engineering Research Institute, Peechi, 1971, pp. 7.1-7.15.

9. Parvathy, K. G., Noujas, V., Thomas, K. V. and Ramesh, H., Impact of mudbanks on coastal dynamics, Aquatic Procedia, 2015, 4, 1514-1521.

10. Pinkerton, Collection of voyages and travels. Administration Report of 1860 of Travancore.

11. Dinesh Kumar, P. K., Balachandran, K. K., Prasanna Kumar, S. and Ramaiah, N., Workshop on mudbank. Indian J. Mar. Sci., 2014, 42, 954-955.

12. Regunathan, A., Mathew, K. J., Rao, D. S., Gopinathan, C. P., Surendranatha Kurup, N. and Murty, A. V. S., Fish and fisheries of mudbank, Bull. Cent. Mar. Fish. Res. Inst., 1984, 31, 60-71.

13. Grasshoff, K., Ehrhardt, M. and Kremling, K., In Methods of Seawater Analysis, Verlag Chemie, Weinheim, Germany, 1983, pp. 89-224.

14. Gupta, G. V. M. et al., Evolution to decay of upwelling and associated biogeochemistry over the southeastern Arabian Sea shelf. J. Geophys. Res. Biogeosci., 2015, 121, 159-175; doi:10.1002/ 2015JG003163.

15. Antony, M. K. and Unnikrishnan, A. S., On an upwelling front, propagation of upwelling and vertical velocity in the eastern Arabian Sea during monsoon, 1987. In Proceedings of the conference for Pacific Ocean Environments and Probing, Okinawa, 1992, vol. 1, pp. 527-532.

ACKNOWLEDGEMENTS. This study is a part of the Alappuzha Mudbank Process Studies (AMPS), a joint programme between CSIRNational Institute of Oceanography (CSIR-NIO), Goa, its Regional Centre at Kochi and Central Marine Fisheries Research Institute (CMFRI), Kochi. We thank all the AMPS participants for their support during data collection, analysis and discussion, and Mentor Group of CSIR-NIO for facilitation. We also thank the Council of Scientific and Industrial Research, New Delhi and CMFRI, for financial support and encouragement. This is NIO contribution number 6199.

Received 16 February 2017; revised accepted 20 March 2018

doi: $10.18520 / \mathrm{cs} / \mathrm{v} 115 / \mathrm{i} 4 / 773-778$ 